\title{
Decontamination of Surgical Instruments for Safe Wound Care Surgeries in Disasters: What are the Options? A Scoping Review
}

\author{
Anna Rowinski, MD; $\odot$ Johan von Schreeb, MD, PhD
}

\author{
Department of Global Public Health, \\ Karolinska Institutet, Stockholm, Sweden \\ Correspondence: \\ Johan von Schreeb, MD, PhD \\ Karolinska Institutet \\ Department of Global Public Health \\ Karolinska Institutet SE-171 77 Stockholm, \\ Sweden \\ E-mail: johan.von.schreeb@ki.se
}

Conflicts of interest: The authors declare that they have no conflicting interests.

Keywords: decontamination; disasters; disinfection; sterilization; surgical instruments

\begin{abstract}
Abbreviations:
EMT: Emergency Medical Team PRISMA: Preferred Reporting Items for Systematic Reviews and Meta-Analyses WHO: World Health Organization
\end{abstract}

Received: March 27, 2021

Revised: June 23, 2021

Accepted: July 10, 2021

\section{doi:10.1017/S1049023X2100090X}

(C) The Author(s), 2021. Published by Cambridge University Press on behalf of the World Association for Disaster and Emergency Medicine. This is an Open Access article, distributed under the terms of the Creative Commons Attribution licence (http:// creativecommons.org/licenses/by/4.0/), which permits unrestricted re-use, distribution, and reproduction in any medium, provided the original work is properly cited.

\begin{abstract}
International guidelines stipulate that autoclavation is necessary to sterilize surgical equipment. World Health Organization (WHO) guidelines for decontamination of medical devices require four levels of decontamination: cleaning, low- and high-level disinfection, as well as sterilization. Following disasters, there is a substantial need for wound care surgery. This requires prompt availability of a significant volume of instruments that are adequately decontaminated. Ideally, they should be sterilized using an autoclave, but due to the resource-limited field context, this may be impossible. The aim of this study was therefore to identify whether there are portable and less resource-demanding techniques to decontaminate surgical instruments for safe wound care surgery in disasters. A scoping review was chosen, and searches were performed in three scientific databases, grey literature, and included data from organizations and journals. Articles were scanned for decontamination techniques feasible for use in the resource-scarce disaster setting given that: they achieved at least high-level disinfected instruments, were portable, and did not require electricity. A total of 401 articles were reviewed, yielding 13 articles for inclusion. The study identified three techniques: pressure cooking, boiling, and liquid chemical immersion, all achieving either sterilized or high-level disinfected instruments. It was concluded that besides autoclaves, there are less resource-demanding decontamination techniques available for safe wound surgery in disasters. This study provides systematic information to guide optimal standard setting for sterilization of surgical material in resource-limited disaster settings.
\end{abstract}

Rowinski A, von Schreeb J. Decontamination of surgical instruments for safe wound care surgeries in disasters: what are the options? A scoping review. Prehosp Disaster Med. 2021;36(5):645-650.

\section{Introduction}

Disasters are events that kill, maim, and create needs that exceed available health care capacities. Natural disasters such as typhoon and flooding cause a significant burden of minor injuries requiring surgical wound care. ${ }^{1-3}$ This requires surgical instruments that must be decontaminated to avoid transmission of pathogens. ${ }^{4,5}$ There are different degrees of decontamination: clean, disinfected, and sterile., ${ }^{5,6}$ Disinfected means that microorganisms have been destroyed or removed but does not necessarily include destruction of bacterial spores. Sterilization is the process used to render an object free from viable microorganisms, including viruses and bacterial spores, but not prions. ${ }^{6,7}$ The Spaulding classification is a widely accepted classification for decontamination of medical devices. ${ }^{5}$ Surgical instruments and other reusable medical devices are classified into Critical, Semi-Critical, and NonCritical devices based on their risk to spread infections. ${ }^{5,7}$ Sterilized instruments (critical devices) are mandatory for surgery on intact skin while high-level disinfected instruments (semi-critical devices) are considered sufficient for non-intact skin, such as open wounds. ${ }^{4,7}$ Common microbes found in open wounds are eradicated when instruments are disinfected. ${ }^{7,8}$ However, spores from a few spore-forming bacteria may survive disinfection and potentially cause infections. However, it remains unclear to what extent this has clinical value in the disaster setting where wounds already are contaminated.

Following the chaos of unregulated international health care assistance after the 2010 Haiti earthquake, the World Health Organization (WHO; Geneva, Switzerland) and partners developed standards and classification for Emergency Medical Teams (EMTs) deployed to natural disasters. ${ }^{9}$ In these, EMT Type 1 provides fixed or mobile out-patient 
care including basic wound care. ${ }^{9}$ The EMT standards stipulate that wound care should only be done with disposable or autoclaved instruments using high pressure and steam. ${ }^{9}$ However, EMT Type 1 mobile experiences from the 2015 earthquake in Nepal, as well as the 2019 Mozambique typhoon, have highlighted significant logistical problems (ie, weight, size, and lack of electricity) with bringing an autoclave or sufficient disposable instruments to remotely affected areas to manage a significant number of minor wounds. To ensure rapid and mobile health response to disasters, there is need for decontamination techniques that are safe but also easy to both deploy and use in a resource-scarce field setting. This article aims to assess portable and non-electricity-dependent alternative techniques for safe decontamination of surgical material for minor wound surgery in disaster settings.

\section{Materials and Methods}

This scoping review followed established scoping review methodology defined by Arksey and O'Malley. ${ }^{10}$ The Preferred Reporting Items for Systematic Reviews and Meta-Analyses Extension for Scoping Reviews (PRISMA-ScR) protocol ${ }^{11}$ was used. Three databases were searched (PubMed [National Center for Biotechnology Information, National Institutes of Health; Bethesda, Maryland USA], Web of Science [Thomson Reuters; New York, New York USA], and Global Health [EBSCO Information Services; Ipswich, Massachusetts USA]); grey literature via additional databases (Global Index Medicus [WHO; Geneva, Switzerland], Popline [Johns Hopkins Bloomberg School of Public Health; Baltimore, Maryland USA], Grey Matters [CADTH; Ottawa, Ontario, Canada], BASE, WHO HQ, JBI [Ovid Technologies; New York, New York USA], and INAHTA [Institute of Health Economics; Edmonton, Alberta, Canada]); data from relevant organizations (WHO, Médecins Sans Frontières [MSF; Geneva, Switzerland], and the International Committee of the Red Cross [ICRC; Geneva, Switzerland]); and various journals.

Articles were scanned for safe and feasible decontamination techniques. A technique was considered feasible if it was portable or did not require a power grid. Portability in this study is defined using the International Air Transport Association (IATA; Montreal, Quebec, Canada) recommended weight limit, stating that the maximum weight of any single piece should not exceed $23 \mathrm{kgs} .{ }^{12}$ Minor wound surgery was defined as surgical management of already open and contaminated minor wounds that can be managed at a primary health service level such as EMT Type 1. A technique was considered safe if it achieved semi-critical decontamination level by either sterilization or high-level disinfection. A thematic analysis of the findings was performed and a numerical summary of the searches outlined using a PRISMA flowchart. ${ }^{11,13}$ The results were compiled in two tables.

\section{Results}

The search rendered 401 articles that were screened for eligibility (Figure 1). Following screening, a total of 13 records matched the inclusion criteria. The 13 studies described six techniques, out of which three were easily available for use or purchase. The identified techniques achieving either sterilized or high-level disinfected instruments were pressure cooking, boiling, and liquid chemical immersion. They are all portable techniques and do not require a power grid.
The feasible and safe techniques identified in this study are presented in two tables and are shown as either achieving sterilized or high-level disinfected instruments. Table $1^{14-27}$ contains a brief introduction of the techniques. The attributes of the techniques are presented in Table 2: portability, chamber volume, cycle time, and whether it requires a power grid or not.

\section{Discussion}

This scoping study found 13 articles presenting six techniques that can sufficiently decontaminate instruments for safe minor wound surgery and seem feasible to use in disaster settings. The identified techniques are easier to use and transport to remotely affected disaster areas compared to heavy and electricity-dependent autoclaves. It was found that safe alternatives to more resource-demanding autoclaves that are currently defined as minimum standards for EMT Type 1 are available. ${ }^{9}$ Pressure cooking, liquid chemicals, and boiling are the techniques that can easily be available for purchase or use today. Pressure cooking or boiling are the most favorable techniques, considering the potential toxicity and residue of liquid chemicals. ${ }^{5,6}$ In addition, the WHO does not recommend liquid chemicals for sterilization. It is difficult to control the process and there is a risk of contamination during the rinse of residual chemicals before patient use. ${ }^{4,6}$ Pressure cooking for 15-40 minutes achieves a higher level of decontamination than boiling for 20 minutes. A pressure cooker can be purchased on local markets while boiling is even easier to achieve with limited resources. In addition, pressure cooking and boiling are more sustainable than disposables and do not require transportation of large quantities of disposables in order to perform the number of wound surgeries often needed after a disaster.

According to Spaulding, high-level disinfected instruments are acceptable for instruments in contact with non-intact skin, ${ }^{4,5,7}$ but what are the safety implications of using high-level disinfected instead of sterilized instruments in a disaster setting? A systematic review focusing on the nature of wounds in disaster situations studied the most common organisms of infected wounds. ${ }^{28}$ All of those pathogens are removed with high-level disinfection. ${ }^{5}$ However, it remains undocumented to what extent high-level disinfected instruments could pose risks in the disaster setting as spores are not fully eliminated. Spores of concern in the disaster setting are Clostridium perfringens and tetani. Tetanus cases have been reported following natural disasters in areas with low tetanus vaccination coverage. ${ }^{29}$ While non-sterile instruments theoretically could spread tetanus, this has not been documented in practice. Poor early wound care is often complicated by more extensive infection and tissue necrosis, gangrene, sepsis, and mortality. ${ }^{30}$ Wound infections and complications including tetanus may develop if surgical cleaning and debridement is not adequately carried out. Spore transmission and infection could besides debridement be avoided (but not replaced) by preventive antibiotic regimes. ${ }^{28}$ With this in mind, one should aim to autoclave instruments, but when this is not feasible, pressure cooking is an acceptable alternative if combined with tetanus prophylaxis.

\section{Methodological Considerations/Limitations}

The scoping review methodology enables searching both published and unpublished material, suitable in this area where important evidence might not yet have been published. Nonetheless, using such a broad search scope makes is challenging to establish boundaries. Therefore, a well-defined search 

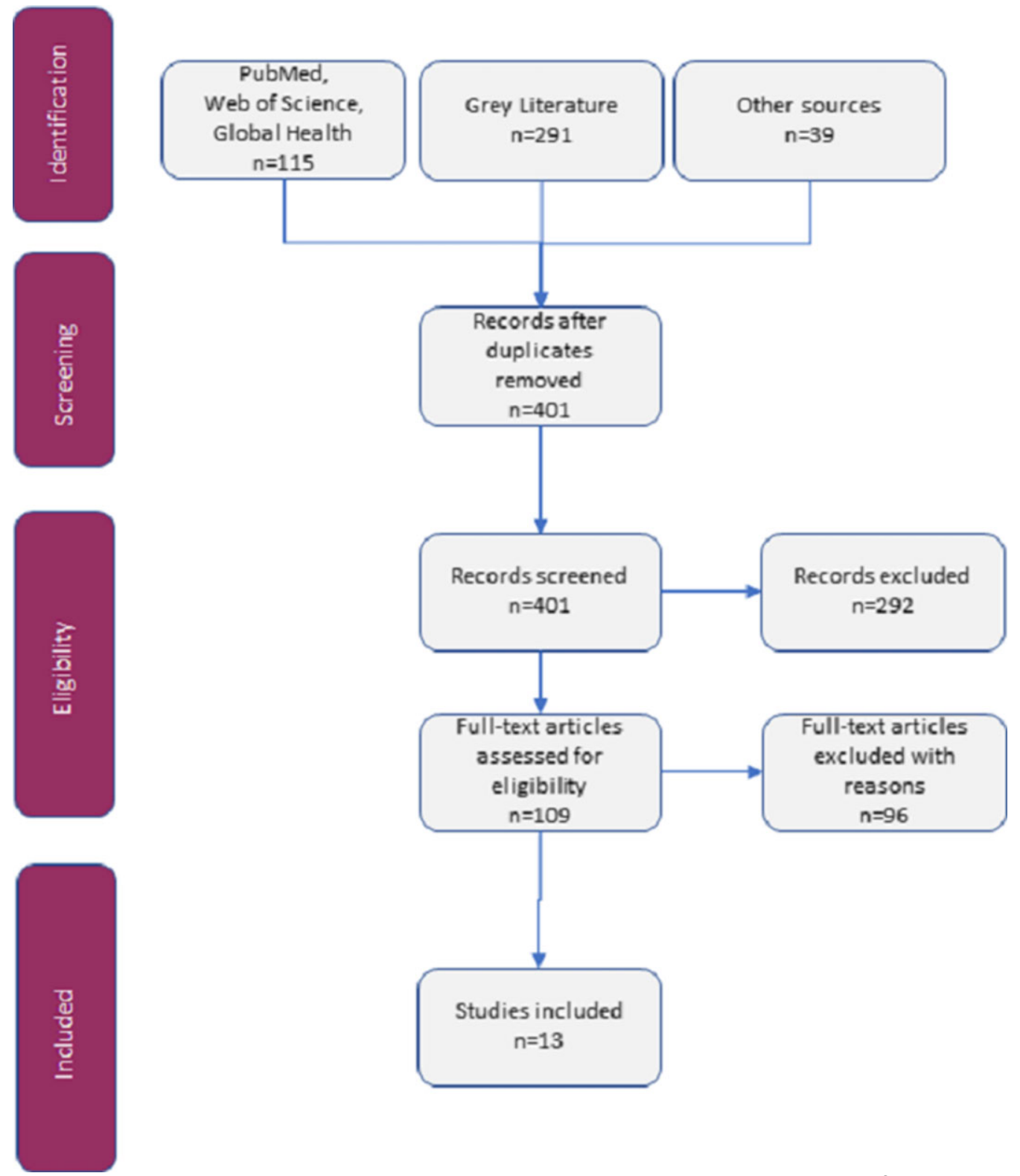

Rowinski @ 2021 Prehospital and Disaster Medicine

Figure 1. PRISMA-ScR Flowchart: Search Results.

Abbreviation: PRISMA-ScR, Preferred Reporting Items for Systematic Reviews and Meta-Analyses Extension for Scoping Reviews.

strategy was developed. For this project, other methods could have been relevant to use, for example, a qualitative interviewbased method. However, this would impose the risk of only increasing knowledge about current processes, not finding research on new developments. Another example is a systematic review which might have yielded a larger number of articles, yet carrying the risk of missing important evidence from unpublished sources. It would also have been interesting to compare these results with similar research, but no previous research in a similar area was found. In summary, a scoping study is particularly relevant to disciplines with emerging evidence such as this study.

\section{Conclusion}

This study found alternative safe, easily deployable, and feasible techniques to decontaminate surgical instruments for wound management in disaster settings, such as pressure cookers, boiling, and liquid chemicals. The study result suggests that current EMT Type 1 decontamination standards for minor wound surgery instruments could be adapted. 


\begin{tabular}{|c|c|c|c|c|}
\hline & Technique & Description & Mechanism of Action & Readily Available \\
\hline \multicolumn{5}{|c|}{ Techniques Achieving Sterilization } \\
\hline \multirow[t]{3}{*}{ Portable Sterilization } & \begin{tabular}{|l} 
Portable Nitrogen Dioxide \\
Sterilizer $^{14}$
\end{tabular} & $\begin{array}{l}\text { A polypropylene case, in } \\
\text { the size of a briefcase. }\end{array}$ & \begin{tabular}{|l|} 
Non-steam autoclave using \\
nitrogen dioxide gas.
\end{tabular} & No \\
\hline & $\begin{array}{l}\text { Portable Chlorine Dioxide } \\
\text { Sterilizer }{ }^{15,16}\end{array}$ & $\begin{array}{l}\text { A plastic case, in the size of } \\
\text { a briefcase. Developed by } \\
\text { Natick Soldier Center. } \\
\end{array}$ & $\begin{array}{l}\text { Non-steam autoclave using } \\
\text { chlorine dioxide gas. }\end{array}$ & No \\
\hline & $\begin{array}{l}\text { ROSS M1 Portable Ozone } \\
\text { Sterilizer }^{17}\end{array}$ & $\begin{array}{l}\text { A plastic case in the size of } \\
\text { a briefcase. Developed for } \\
\text { and evaluated by US } \\
\text { Special Forces. }\end{array}$ & $\begin{array}{l}\text { Non-steam autoclave using } \\
\text { peroxone gas. }\end{array}$ & No \\
\hline Pressure Cooking & $\begin{array}{l}\text { Specially Designed Low- } \\
\text { Cost Autoclave }{ }^{18}\end{array}$ & $\begin{array}{l}\text { Developed at MIT for and } \\
\text { used by health care centers } \\
\text { in Nepal and marketed } \\
\text { under the brand } \\
\text { OttoClave. }{ }^{19}\end{array}$ & $\begin{array}{l}\text { Design included a heating } \\
\text { element, pressure cooker, } \\
\text { pressure sensor, and mon- } \\
\text { itor. }\end{array}$ & Unknown \\
\hline Liquid Chemical Immersion & Liquid Chemicals ${ }^{23}$ & $\begin{array}{l}\text { A number of liquid chemi- } \\
\text { cals available, achieving } \\
\text { sterility if soaked for up to } 12 \\
\text { hours. The most common is } \\
\text { glutaraldehyde. }\end{array}$ & $\begin{array}{l}\text { Inactivates microbes if } \\
\text { instruments are properly } \\
\text { cleaned.23 }\end{array}$ & Yes \\
\hline \multirow[t]{2}{*}{ Solar Driven } & $\begin{array}{l}\text { Solar Driven Dry Heat } \\
\text { Oven }^{24}\end{array}$ & $\begin{array}{l}\text { Maria Telke's solar oven; } \\
\text { can generate temperatures } \\
\text { above } 180^{\circ} \mathrm{C} \text {. } \\
\end{array}$ & Dry heat. & Unknown \\
\hline & $\begin{array}{l}\text { Broadband Light-Absorbing } \\
\text { Nanoparticles as Solar } \\
\text { Photothermal Heaters }\end{array}$ & $\begin{array}{l}\text { As light is absorbed by a } \\
\text { nanoparticle, a temperature } \\
\text { difference is established } \\
\text { which converts the liquid } \\
\text { into vapor. When the vapor } \\
\text { reaches the surface, it is } \\
\text { released, resulting in steam } \\
\text { generation at lower tem- } \\
\text { peratures than the boiling } \\
\text { point. }\end{array}$ & High-temperature steam. & No \\
\hline UVC Light & $\begin{array}{l}\text { Chlorhexidine Scrub + } \\
\text { UVC Light }{ }^{26}\end{array}$ & $\begin{array}{l}\text { Each instrument exposed } \\
\text { to UVC light radiation by } \\
\text { waving the wand up and } \\
\text { down the side of the instru- } \\
\text { ment for } 45 \text { seconds. }\end{array}$ & $\begin{array}{l}\text { UVC light disrupts the DNA } \\
\text { of microorganisms. }\end{array}$ & No \\
\hline \multicolumn{5}{|c|}{ Techniques Achieving High-Level Disinfection } \\
\hline Boiling & Boiling ${ }^{27}$ & $\begin{array}{l}\text { According to WHO guide- } \\
\text { lines on sterilization and } \\
\text { disinfection methods effec- } \\
\text { tive against HIV (1989), if } \\
\text { sterilization is not possible, } \\
\text { high-level disinfection by } \\
\text { boiling for } 20 \text { minutes is } \\
\text { acceptable. }^{27}\end{array}$ & High temperature. & $\begin{array}{l}\text { No Specific Appliance } \\
\text { Required }\end{array}$ \\
\hline Liquid Chemical Immersion & Liquid Chemicals ${ }^{23}$ & $\begin{array}{l}\text { A number of liquid chemi- } \\
\text { cals are available, achiev- } \\
\text { ing high-level disinfection if } \\
\text { soaked for } 15-30 \text { minutes. } \\
\text { The most common is glu- } \\
\text { taraldehyde. }\end{array}$ & $\begin{array}{l}\text { Inactivates microbes if } \\
\text { instruments are properly } \\
\text { cleaned. } .^{23}\end{array}$ & Yes \\
\hline
\end{tabular}

Table 1. An Introduction to the Techniques

Rowinski @ 2021 Prehospital and Disaster Medicine Abbreviation: UVC light, ultraviolet $\mathrm{C}$ light 


\begin{tabular}{|c|c|c|c|c|c|}
\hline & Technique & Portability & $\begin{array}{l}\text { Requires a Power } \\
\text { Grid }\end{array}$ & Chamber Volume & Cycle Time \\
\hline \multicolumn{6}{|c|}{ Techniques Achieving Sterilization } \\
\hline \multirow[t]{3}{*}{ Portable Sterilization } & \begin{tabular}{|l|} 
Portable Nitrogen Dioxide \\
Sterilizer $^{14}$
\end{tabular} & Yes & No & $9 \mathrm{~L}$ & 3-8 hours \\
\hline & \begin{tabular}{|l|} 
Portable Chlorine Dioxide \\
Sterilizer $^{15,16}$
\end{tabular} & Yes & No & $n / a$ & 30 minutes \\
\hline & \begin{tabular}{|l|} 
ROSS M1 Portable Ozone \\
Sterilizer $^{17}$
\end{tabular} & Yes & No & $18 \mathrm{~L}$ & 45 minutes \\
\hline \multirow[t]{3}{*}{ Pressure Cooking } & $\begin{array}{l}\text { Specially Designed Low-Cost } \\
\text { Autoclave }{ }^{18}\end{array}$ & Yes & No & $n / a$ & 30 minutes \\
\hline & \begin{tabular}{|l|} 
Local Market Pressure \\
Cooker20
\end{tabular} & Yes & No & $12 \mathrm{~L}$ & $30-40$ minutes \\
\hline & $\begin{array}{l}\text { Four Local Market Pressure } \\
\text { Cookers }^{21}\end{array}$ & Yes & No & $8 \mathrm{~L}$ & $\begin{array}{l}15 \text { minutes/ } \\
16 \text { psi } \\
40 \text { minutes/ } \\
13 \text { psi }\end{array}$ \\
\hline $\begin{array}{l}\text { Liquid Chemical } \\
\text { Immersion }\end{array}$ & Liquid Chemicals ${ }^{23}$ & Yes & No & $n / a$ & Up to 12 hours \\
\hline \multirow[t]{2}{*}{ Solar Driven } & Solar Driven Dry Heat Oven ${ }^{24}$ & Yes & No & $n / a$ & $\begin{array}{l}40 \text { minutes } \\
\text { at } 180^{\circ}\end{array}$ \\
\hline & \begin{tabular}{|l|} 
Broadband Light-Absorbing \\
Nanoparticles as Solar \\
Photothermal Heaters ${ }^{25}$
\end{tabular} & Yes & No & $14.2 \mathrm{~L}$ & 30 minutes \\
\hline UVC Light & $\begin{array}{l}\text { Chlorhexidine Scrub + UVC } \\
\text { Light }^{26}\end{array}$ & Yes & No & $n / a$ & 45 seconds \\
\hline \multicolumn{6}{|c|}{ Techniques Achieving High-Level Disinfection } \\
\hline Boiling & Boiling $^{27}$ & Yes & No & $\mathrm{n} / \mathrm{a}$ & 20 minutes \\
\hline
\end{tabular}

Table 2. Techniques that are Portable and do not Require a Power Grid

Note: Not applicable (n/a) - the information could not be found.

Abbreviations: PSI, pound-force per square inch (unit of pressure); UVC light, ultraviolet C light.

References

1. World Health Organization. Definitions: emergencies. http://www.who.int/hac/ about/definitions/en/. Accessed December 1, 2019.

2. Bartholdson S, von Schreeb J. Natural disasters and injuries: what does a surgeon need to know? Curr Trauma Rep. 2018;4(2):103-108.

3. Centurion MT, Van Den Bergh R, Gray H. Anesthesia provision in disasters and armed conflicts. Curr Anesthesiol Rep. 2017;7(1):1-7.

4. Leaper DJ, Edmiston CE. World Health Organization: global guidelines for the prevention of surgical site infection. J Hosp Infect. 2017;95(2):135-136.

5. Rutala WA, Weber DJ. Disinfection and Sterilization in Healthcare Facilities. https://www.cdc.gov/infectioncontrol/guidelines/disinfection/. Accessed March 2021.

6. WHO. Decontamination and Reprocessing of Medical Devices for Health Care Facilities. http://apps.who.int/iris/bitstream/handle/10665/250232/9789241549851eng.pdf;jsessionid=CE6E92207526D7C219CD1A9A09CF462A?sequence = 1. Accessed December 15, 2018.

7. ICRC Sterilization Guidelines. http://icrcndresourcecentre.org/wp-content/uploads/ 2015/04/sterlization.pdf. Accessed December 1, 2019.

8. Bessa LJ, Fazii P, Di Giulio M, et al. Bacterial isolates from infected wounds and their antibiotic susceptibility pattern: some remarks about wound infection. Int Wound J. 2015;12(1):47-52.

9. WHO. Classification and Minimum Standards for Foreign Medical Teams in Sudden Onset Disasters. http://www.who.int/entity/csr/resources/publications/ebola/foreignmedical-teams/en/index.html. Accessed December 1, 2019.

10. Arksey H, O’Malley L. Scoping studies: towards a methodological framework. Int J Soc Res Methodol. 2005;8(1):19-32.
11. Tricco AC, Lillie E, Zarin W, et al. PRISMA Extension for Scoping Reviews (PRISMA-ScR): Checklist and Explanation. Ann Intern Med. 2018;169(7):467.

12. IATA. Passenger Baggage Information. https://www.iata.org/whatwedo/ops-infra/ baggage/pages/check-bag.aspx. Accessed October 28, 2018.

13. Moher D, Liberati A, TetzlaffJ, et al; PRISMA Group. Preferred reporting items for systematic reviews and meta-analyses: the PRISMA statement. Open Med. 2009;3(3):e123-130.

14. Shomali M, Opie D, Avasthi T, et al. Nitrogen dioxide sterilization in low-resource environments: a feasibility study. PLoS One. 2015;10(6):e0130043.

15. Doona CJ, Feeherry FE, Kustin K, et al. Fighting Ebola with novel spore decontamination technologies for the military. Front Microbiol. 2015;6:663.

16. Doona CJ, Feeherry FE, Setlow P, et al. The Portable Chemical Sterilizer (PCS), D-FENS, and D-FEND ALL: novel chlorine dioxide decontamination technologies for the military. J Vis Exp. 2014;(88):e4354.

17. Rugged Ozone Sterilization System from SteriO3. Rugged, Portable, BatteryPowered Field Sterilization System. https://sterio3.com/. Accessed December 2, 2018.

18. Cho HS, Tao GD, Winter A. Achieving appropriate design for developing world heath care: the case of a low-cost autoclave for primary health clinics. Conf Proc IEEE Eng Med Biol Soc. 2012;2012:2400-2403.

19. Design with Benefits. http://www.designwithbenefits.com/the-dish/ottoclave-lowcost-medical-sterilization-via-pressure-cooker. Accessed December 21, 2018.

20. Balraj V, Sridharan G, John TJ. Sterilization of syringes and needles for immunization programs using a pressure cooker. J Trop Med Hyg. 1990;93(2):119-120.

21. US Department of Defense. Using Commercial Pressure Cookers to Sterilize Dental Instruments in Remote Settings. http://azahec.uahs.arizona.edu/sites/ 
default/files/u132/19-arnett_rhpp_pressure_cooker.pdf. Accessed December 1, 2018.

22. Barone MA, Faisel AJ, Andrews L, et al. Adaptation and validation of a portable steam sterilizer for processing intrauterine device insertion instruments and supplies in low-resource settings. Am J Infect Control. 1997;25(4):350-356.

23. Rutala WA, Weber DJ. Disinfection, sterilization, and antisepsis: an overview. $A m J$ Infect Control. 2016;44(5 Suppl):e1-e6.

24. Jørgensen AF, Nøhr K, Boisen F, et al. Sterilization of instruments in solar ovens. J Appl Microbiol. 2002;93(6):1059-1064.

25. Neumann O, Feronti C, Neumann AD, et al. Compact solar autoclave based on steam generation using broadband light-harvesting nanoparticles. Proc Natl Acad Sci USA. 2013;110(29):11677-11681.
26. Knox RW, Demons ST, Cunningham CW. A novel method to decontaminate surgical instruments for operational and austere environments. Wilderness Environ Med. 2015;26(4):509-513.

27. WHO AIDS Series Vol 2. Ann Intern Med. 1990;113(7):564.

28. Wuthisuthimethawee P, Lindquist SJ, Sandler N, et al. Wound management in disaster settings. World J Surg. 2015;39(4):842-853.

29. Pascapurnama DN, Murakami A, Chagan-Yasutan H, et al. Prevention of tetanus outbreak following natural disaster in Indonesia: lessons learned from previous disasters. Tohoku J Exp Med. 2016;238(3):219-227.

30. WHO. Prevention and Management of Wound Infection. https://www.who.int/hac/ techguidance/tools/guidelines_prevention_and_management_wound_infection. pdf?ua=1. Accessed November 10, 2019. 